Studia nad Autorytaryzmem i Totalitaryzmem 41, nr 4 Wrocław 2019

DOI: $10.19195 / 2300-7249.41 .4 .8$

\author{
JAROSŁAW KOSTRUBIEC \\ ORCID: 0000-0003-1379-9846
}

Uniwersytet Marii Curie-Skłodowskiej w Lublinie

\title{
Z dziejów administracji państwa stanu wyjątkowego. Ustrój administracji publicznej na terenach byłego zaboru austriackiego u progu II Rzeczypospolitej
}

\begin{abstract}
Rząd, jaki powstał w Warszawie, uważamy za polski rząd narodowy, lecz nim obejmie on w zupełności władzę nad całą Polską, musimy przyjść mu z pomocą przy zorganizowaniu kraju ${ }^{1}$.
\end{abstract}

Proces budowy struktur administracji publicznej w początkach państwa polskiego na terenach byłych trzech zaborów miał różny przebieg. W każdym przypadku przyjęcie określonych rozwiązań ustrojowo-prawnych było związane z okolicznościami natury politycznej i prawnomiędzynarodowej, w tym z historią upadku rządów okupacyjnych i walką o kształt granic państwa polskiego ${ }^{2}$. Istotne znaczenie miały także dotychczas obowiązujące regulacje ustrojowo-prawne danego państwa zaborczego ${ }^{3}$. Głównym celem podjętych rozważań - z związku z przywołanym mottem, które stanowią słowa Wincentego Witosa - jest ukazanie specyfiki procesu organizowania administracji publicznej i określenie jej modelu na terenach byłego zaboru austriackiego w okresie odbudowy państwa polskiego. W tytule artykułu

1 Zgromadzenie postów w Krakowie, „Głos Narodu” 28.11.1918 (wydanie wieczorne), s. 2.

2 Por. I. Hoffman, The changes of the roles of the Hungarian counties: Towards a one and a half-tier system?, „Lex Localis - Journal Of Local Self-Government” 12, 2014, nr 3, s. 398; P. Dąbrowski, Rozpolitykowane miasto. Ustrój polityczny państwa w koncepcjach polskich ugrupowań działających w Wilnie w latach 1918-1939, Gdańsk 2012, s. 437-460; A. Bosiacki, Od naturalizmu do etatyzmu. Doktryny samorzadu terytorialnego Drugiej Rzeczpospolitej 1918-1939, Warszawa 2006, s. 39-43; J. Przygodzki, Komisje dla usprawnienia administracji publicznej w II Rzeczypospolitej. Studium historycznoprawne, Wrocław 2019, s. 36.

3 Por. J. Kostrubiec, Administracja ogólna w myśli prawniczej Drugiej Rzeczypospolitej, Warszawa 2019, s. 24-25.

Studia nad Autorytaryzmem i Totalitaryzmem 41, nr 4, 2019

(C) for this edition by CNS 
wykorzystano pojęcie ,państwo stanu wyjątkowego”. Nie użyłem go jednak w takim znaczeniu, w jakim uczynił to Franciszek Ryszka (1924-1998) ${ }^{4}$. Celem było raczej zwrócenie uwagi czytelnika na warunki, w jakich dokonywała się restytucja państwa polskiego. Procesowi odbudowy Rzeczypospolitej towarzyszyły bowiem szczególne okoliczności o charakterze politycznym, prawnym i militarnym, w jakich musiała funkcjonować polska administracja ${ }^{5}$.

Początki polskiej administracji publicznej na terenach byłego zaboru austriackiego były związane z utworzeniem przez polskich posłów 28 października 1918 roku w Krakowie Polskiej Komisji Likwidacyjnej ${ }^{6}$. Powołali ją reprezentanci najważniejszych polskich ugrupowań politycznych w Galicji oraz przedstawiciele Śląska Cieszyńskiego ${ }^{7}$, gdzie powstał w istocie pierwszy polski organ władzy na terenach byłego zaboru austriackiego, jakim była Rada Narodowa Księstwa Cieszyńskiego. Przewodniczącym Polskiej Komisji Likwidacyjnej został Wincenty Witos (1874-1945). W skład prezydium komisji weszli: Ignacy Daszyński (1866-1936), ks. Józef Londzin (1862-1929), hr. Aleksander Skarbek (1874-1922) i Tadeusz Tertil (1864-1925) ${ }^{8}$. W Wiedniu Polską Komisję Likwidacyjną reprezentował ostatni minister dla Galicji w rządzie austriackim Kazimierz Gałecki (1863-1941) ${ }^{9}$. Na posiedzeniu Komisji 28 października przyjęto rezolucję, że ziemie polskie w obrębie monarchii austro-węgierskiej należały do państwa polskiego ${ }^{10}$. Dzień później prezydium komisji wydało okólnik skierowany do organów rządowych i autonomicznych o zakazie przyjmowania rozkazów od władz obcych, jeżeli sprzeciwiały się polskim interesom narodowym ${ }^{11}$. Status

${ }^{4}$ Por. F. Ryszka, Państwo stanu wyjątkowego. Rzecz o systemie państwa i prawa Trzeciej Rzeszy, Wrocław-Warszawa-Kraków 1964, s. 455.

5 Por. zwł. P.K. Marszałek, Stany wyjątkowe na Śląsku w latach 1918-1922, „Prawo” 285, 2003, s. 292-293; idem, Sady doraźne na ziemiach polskich po I wojnie światowej (listopad 1918luty 1919), „Prawo” 169, 1989, s. 135-138; M. Bożek, Ksztalt ustawodawstwa stanów nadzwyczajnych w okresie odbudowy państwowości (1918-1921), „Studia Iuridica Lublinensia” 16, 2011, s. 95-97.

6 „Dla tych ziem postanowiono utworzyć Polską Komisję Likwidacyjną złożoną z 22 posłów wybranych według klucza partyjnego i jednego przedstawiciela Śląska Cieszyńskiego" - W. Witos, Upadek Austrii i Polska Komisja Likwidacyjna, [w:] Rok 1918 we wspomnieniach mężów stanu, polityków $i$ wojskowych, wybór i oprac. J. Borkowski, Warszawa 1987, s. 30. Por. K.W. Kumaniecki, Ustrój państwowych władz administracyjnych na ziemiach Polski, Kraków 1920, s. 126.

7 Por. A. Ajnenkiel, Od rządów ludowych do przewrotu majowego. Zarys dziejów politycznych Polski 1918-1926, Warszawa 1977, s. 8-9. Konsultacje w sprawie powołania w Galicji tymczasowych władz polskich trwały już od początku października 1918 roku. W rozmowach brali udział przedstawiciele trzech stronnictw politycznych — PSL „Piast”, Narodowej Demokracji i Polskiej Partii Socjalno-Demokratycznej Galicji i Śląska. Por. M. Przeniosło, Polska Komisja Likwidacyjna 1918-1919, Kielce 2010, s. 16-17.

8 Z. Lasocki, Wspomnienia szefa administracji P.K.L. i K.Rz., Kraków 1931, s. 8.

9 Por. A. Tarnowska, Z dziejów unifikacji administracji II Rzeczypospolitej. Rola przepisów pruskich, Toruń 2012, s. 39.

10 Z. Lasocki, op. cit., s. 8.

11 Por. K. Bąkowski, Kronika Krakowa z lat 1918-1923 z ilustracjami, Kraków 1925, s. 7.

Studia nad Autorytaryzmem i Totalitaryzmem 41, nr 4, 2019

(C) for this edition by CNS 
Polskiej Komisji Likwidacyjnej nie był początkowo klarowny ${ }^{12}$. Rozważano przyznanie jej funkcji rządu dzielnicowego, jak też realizację zadań wyłącznie w charakterze komisji likwidacyjnej ${ }^{13}$. Rada Regencyjna Królestwa Polskiego na wniosek Rady Ministrów 31 października 1918 roku mianowała Komisarzem Generalnym Rządu Polskiego dla Galicji i polskiej części Śląska ks. Witolda Czartoryskiego (1864-1945). Jego zastępcą został Stefan Bądzyński (1869-1928) ${ }^{14}$. Do zadań Komisarza miało należeć przygotowanie i przeprowadzenie przejęcia całego zarządu państwowego przez polskie władze państwowe ${ }^{15}$. Podczas spotkania Komisarza Generalnego z Prezydium Polskiej Komisji Likwidacyjnej, które odbyło się 3 listopada 1918 roku w Krakowie, nie osiągnięto jednak porozumienia w sprawie przekazania władzy W. Czartoryskiemu ${ }^{16}$. Następnego dnia Polska Komisja Likwidacyjna ukonstytuowała się jako rząd dzielnicowy w zmienionym składzie prezydium ${ }^{17} \mathrm{i}$ z wyodrębnionymi 12 wydziałami o charakterze resortowym, którymi kierowali naczelnicy ${ }^{18}$.

Początki funkcjonowania administracji terytorialnej związane były ze strukturami określanymi mianem „komitetów powiatowych”, „powiatowych komitetów narodowych” lub „powiatowych komisji likwidacyjnych”19 , które „przeważ-

12 „W obradach poniedziałkowego zebrania poselskiego w Krakowie zaznaczyła się silnie niejasność myśli co do celu instytucji, jaką miano stworzyć. [...] Nowo wybrane ciało nazwano Komisją likwidacyjną, którą ono zgoła nie jest, gdyż pomyślane zostało jako rodzaj przejściowego rządu” - S. Kutrzeba, Odbiór Galicji, „Głos Narodu” 30.10.1918, s. 1.

13 Znamienne w tym względzie było stanowisko Stanisława Głąbińskiego, który był zwolennikiem utworzenia „komisji likwidacyjnej polsko-austriacko-węgierskiej dla przeprowadzenia likwidacji stosunku (zwierzchności państwowej Austrii) do Polski i Śląska na rzecz Polski” — idem, Odkąd Polska jest państwem niepodległym?, Warszawa 1931, s. 16. Por. A. Tarnowska, op. cit., s. 39.

14 Postanowienie Rady Regencyjnej Królestwa Polskiego z dnia 31 października 1918 roku (M.P. Nr 191).

15 Ibidem.

16 Z. Lasocki, op. cit., s. 19. Spotkanie ks. W. Czartoryskiego z Polską Komisją Likwidacyjną w Krakowie „Głos Narodu” zrelacjonował w sposób następujący: „Książę Witold Czartoryski był oświadczył Komisji Likwidacyjnej, że władzy z nią nie podziela za żadną cenę; wziął ją od rządu polskiego i nie ma prawa nikomu jej ustępować, ani też z kim się z nią obdzielać. Wtedy to stronnictwa, wśród których narodowa demokracja i ludowcy godziły się początkowo na osobę księcia, zwróciły się były przeciwko niemu. Książę nie ustąpił, a że w chwili zupełnie wyjątkowej całej odpowiedzialności na swe barki brać nie mógł, więc i odjechał” — Z Komisji Likwidacyjnej, „Głos Narodu” 5.11.1918 (wydanie poranne), s. 2.

17 Przewodniczącym Prezydium był nadal Wincenty Witos. Nowymi członkami zostali: Jędrzej Moraczewski (1870-1944) — po jego rezygnacji Zygmunt Marek (1872-1931), Tadeusz Tertil (1864-1925) i Józef Ptaś (1864-1942). Por. Z. Lasocki, op. cit., s. 19.

18 Utworzono następujące wydziały: administracji, wojska, rolnictwa, robót publicznych, sądownictwa, skarbu, komunikacji, aprowizacji, opieki społecznej, górnictwa, przemysłu i handlu oraz oświaty. Wydział kultury i sztuki powstał w późniejszym okresie (prawdopodobnie w połowie stycznia 1919 roku). Por. M. Przeniosło, op. cit., s. 25; Z. Lasocki, op. cit., s. 19.

19 M. Przeniosło, op. cit., s. 33; Z. Lasocki, op. cit., s. 32. 
nie składały się [...] częściowo z ludzi poważnych lub popularnych w powiecie. Czasami zasiadały w nich nawet wybitne osobistości" ${ }^{20}$. Przejmowały one władzę administracyjną w powiatach metodą faktów dokonanych. $\mathrm{Z}$ uwagi na niską efektywność sprawowania administracji przez tworzone organy kolegialne Polska Komisja Likwidacyjna podjęła decyzję o przejęciu władzy w powiatach przez mianowanych przez nią komisarzy, którzy mieli wykonywać swoje kompetencje z pomocą tak zwanych rad przybocznych ${ }^{21}$.

Podstawa prawna organizacji i funkcjonowania powiatowej administracji terytorialnej została określona $\mathrm{w}$ dwóch dokumentach datowanych na 6 listopada 1918 roku $^{22}$. Pierwszy z nich, określony mianem dekretu, stanowił akt indywidualny, w którym nie tylko imiennie powoływano daną osobę na stanowisko komisarza PKL, lecz także krótko określano jej zakres kompetencji. Drugi dokument był instrukcją dla komisarzy, w której Wydział Administracyjny Polskiej Komisji Likwidacyjnej określił podstawowe zasady organizacji administracji terytorialnej ${ }^{23}$. Głównym założeniem przyjętego aktu była derogacja zasady dualizmu administracji i połączenie administracji rządowej oraz samorządowej. Dotychczasowe zadania i kompetencje organów powiatowych wraz z działalnością „,zapomogową i aprowizacyjną" miał przejąć Komisarz Polskiej Komisji Likwidacyjnej ${ }^{24}$. Komisarzy w każdym powiecie powoływał wydział administracyjny (naczelnik) Komisji Likwidacyjnej. Utworzonym w ten sposób organom monokratycznym podlegał cały personel starostwa i rady powiatowej. Wydział powiatowy z samorządowego organu wykonawczego miał stać się podmiotem opiniodawczym i kontrolującym. Analogiczne funkcje pełnili delegaci wybierani przez Radę Powiatową Komisji Likwidacyjnej, która nominując ich skład, miała zapewnić możliwie szeroką reprezentację poszczególnych grup społecznych ${ }^{25}$. W ten sposób miała powstać tak zwana rada przyboczna jako organ ,doradczy i kontrolny”. Przy komisarzu powołano komendanta powiatowych straży obywatelskich, do którego należały sprawy administracyjne i bezpieczeństwa publicznego ${ }^{26}$.

Wobec przedstawionej regulacji, której autorem był prawdopodobnie naczelnik wydziału administracyjnego Zygmunt Lasocki (1867-1948) ${ }^{27}$, podnoszono uwagi

20 Z. Lasocki, op. cit., s. 32.

21 Por. M. Przeniosło, op. cit., s. 33-34.

22 Ibidem, s. 52.

23 Rozporządzenie Polskiej Komisji Likwidacyjnej z dnia 6 listopada 1918 roku, Instrukcja dla komisarzy Polskiej Komisji Likwidacyjnej, nr L. 4/ad. (niepublikowane), cyt. za: K.W. Kumaniecki, op. cit., s. 127.

24 Por. Instrukcja dla komisarzy..., pkt 1-2.

25 Por. Instrukcja dla komisarzy..., pkt 3 lit. a-b.

26 K.W. Kumaniecki, op. cit., s. 128.

27 „W dzień po objęciu kierownictwa wydziału administracji, 5-go listopada, przedłożyłem PKL opracowany naprędce projekt organizacji powiatowych władz administracyjnych" — Z Lasocki, op. cit., s. 32. 
krytyczne $^{28}$. Po pierwsze, instytucja komisarzy Polskiej Komisji Likwidacyjnej, w sytuacji gdy został nim dotychczasowy starosta, była zmianą jedynie emblematyczną, co miało miejsce w wypadku 17 powiatów ${ }^{29}$. Po drugie, w przypadku powołania na to stanowisko personalnie innej osoby sytuacja prawna dotychczasowego starosty budziła liczne wątpliwości. Podobny stan rzeczy dotyczył Namiestnictwa z siedzibą we Lwowie. Dodatkowo sytuację prawną komplikowało pozostawienie wydziałów powiatowych z marszałkami. Status komisarza odpowiadał w pewnym zakresie idei administracji ogólnej ${ }^{30}$. Do instrukcji implementowano bowiem zasadę zespolenia personalnego i kompetencyjnego.

Wydział administracyjny PKL 21 listopada 1918 roku wydał rozporządzenie, zgodnie z którym komisje powiatowe miały być ostatecznie zlikwidowane ${ }^{31}$. Organem administracji powiatowej pierwszej instancji został komisarz, przy którym podmiotem doradczym i kontrolującym uczyniono radę przyboczną ${ }^{32}$. W świetle rozporządzenia organem drugiej instancji została Polska Komisja Likwidacyjna.

PKL miała kontrolować teren całej Galicji. Ze względu jednak na szczególne okoliczności związane z przejęciem władzy przez Ukraińców w nocy z 31 października na 1 listopada 1918 roku organizowanie polskiej administracji w Galicji Wschodniej miało inny przebieg ${ }^{33}$. W części Lwowa kontrolowanej przez ludność polską utworzono Komitet Bezpieczeństwa i Ochrony Dobra Publicznego pod przewodnictwem Marcelego Chlamtacza (1865-1947) i Artura Hausnera (1870-1941), w ramach którego wyodrębniono podstawowe resorty administracji $^{34}$. Następnie 22 listopada, po przejęciu Lwowa przez Polaków, podjęto decyzję o utworzeniu Tymczasowego Komitetu Rządzącego ${ }^{35}$. Do organu weszło 20 osób. Wyłoniono prezydium w składzie: Ernest Adam (1868-1926), Edward Dubanowicz (1881-1943), Artur Hausner (1870-1941) i Władysław Stesłowicz

${ }^{28}$ K.W. Kumaniecki, op. cit., s. 128; M. Przeniosło, op. cit., s. 58. „Spółka, która pod postacią komisji likwidacyjnej w Krakowie chwyciła za rządy, rozwinęła sztandar separatyzmu dzielnicowego bynajmniej nie w tym celu, aby zadania rządu na mniejszym obszarze spełnić prędzej i lepiej” - M. Bobrzyński, Wskrzeszenie Państwa Polskiego. Szkic historyczny, t. 2. 1918-1923, Kraków 1925, s. 27.

29 M. Przeniosło, op. cit., s. 52.

30 Por. J. Kostrubiec, op. cit., s. 26-32.

31 „Obecnie, kiedy Polska Komisja Likwidacyjna zamianowała już dla każdego powiatu komisarza, kiedy Rady przyboczne już się ukonstytuowały, kiedy w skład Rad tych weszli z wolnego wyboru w myśl zasad prawdziwie demokratycznych reprezentanci ludu i robotników, którzy wskutek tego zostali dopuszczeni do udziału i kontroli w administracji powiatu, kiedy wreszcie zamianowani zostali Komendanci powiatowych straży, których zadaniem jest czuwać nad bezpieczeństwem osób i mienia — ustaje z natury rzeczy bezpośredni wpływ powiatowej Komisji Likwidacyjnej na administrację powiatu" - Rozporządzenie Wydziału Administracyjnego PKL z dnia 21 listopada 1918 roku, L. 128/Adm. (Dz.R. PKL Cz. I, L. 13, s. 8).

32 Ibidem.

33 Por. A. Ajnenkiel, op. cit., s. 12-13.

34 Por. A.W. Hausner, Listopad 1918. W dziesiąta rocznicę, Lwów 1928, s. 40-41.

35 M. Przeniosło, op. cit., s. 277. 
$(1867-1940)^{36}$. W ramach komitetu powstało 12 referatów ${ }^{37}$ : skarbu — Stanisław Głąbiński; kolei i dróg - Artur Hausner; administracji - Aleksander Skarbek; spraw wojskowych — Edward Dubanowicz; szkolnictwa - Marceli Chlamtacz; ochrony społecznej i spraw sanitarnych — Szczepan Mikołajski; aprowizacji — Adam Kuryłowicz; odbudowy kraju i odszkodowań - Adam Głażewski; sądownictwa - Henryk Loewenherz; przemysłu i handlu - Władysław Stesłowicz; poczt i telegrafów - Bronisław Laskownicki; górnictwa (wakat) ${ }^{38}$.

Polska Komisja Likwidacyjna po wyparciu wojsk ukraińskich ze Lwowa delegowała naczelnika Wydziału Administracyjnego Zygmunta Lasockiego „celem zorganizowania na miejscu administracji i straży bezpieczeństwa dla wschodniej części kraju" ${ }^{39}$. Według jego relacji przejęcie władzy administracyjnej bez zgody Tymczasowego Komitetu Rządzącego było niemożliwe. Komitet nie kwestionował jednak władzy PKL. Uważał się za „tymczasowy organ wykonawczy, powstały z konieczności, gdy nie było faktycznie żadnej innej władzy we Lwowie" 40 . Niemniej jednak podjęto uchwałę o wysłaniu do rządu polskiego w Warszawie noty „o objęciu przez komitet czynności w charakterze tymczasowego organu zastępczego tego rządu aż do dalszych jego poleceń" ${ }^{41}$, co nieco kłóciło się z relacją Z. Lasockiego. W wyniku rozmów zjednoczeniowych między Polską Komisją Likwidacyjną a Tymczasowym Komitetem Rządzącym przygotowano projekt statutu Komisji Rządzącej, który został przesłany do Rady Ministrów w celu zatwierdzenia. Rząd po dokonaniu pewnych modyfikacji ostatecznie statut zatwierdził ${ }^{42}$.

W konsekwencji dekretem Naczelnika Państwa z dnia 10 stycznia 1919 roku powołano Komisję Rządzącą dla Galicji i Śląska Cieszyńskiego oraz Górnej Orawy i Spiszu, której celem oprócz sprawowania bieżącej administracji miało być przygotowanie w porozumieniu z rządem centralnym ,jak najszybszego zupełnego zespolenia" w sensie ustrojowo-prawnym obszaru byłego zaboru austriackiego z resztą ziem państwa polskiego ${ }^{43}$. Komisja była organem władzy stanowiącej i kontrolnej. Miała siedzibę we Lwowie; składała się z 48 przedstawicieli delegowanych przez stronnictwa polityczne ${ }^{44}$. W świetle statutu miała być tymczasowym organem rządu centralnego, który wyposażono w kompetencje o charakterze prawotwórczym i kontrolującym. Władzę wykonawczą sprawował wybierany

${ }^{36}$ Z tymczasowego komitetu rządzacego (komunikat), ,Wiek Nowy. Popularny dziennik ilustrowany" 24.11.1918, s. 1.

37 Ibidem.

38 „Wobec nieobsadzenia dotychczas referatu górnictwa, przydzielono na razie sprawy górnicze do Wydziału handlu i przemysłu” — Komunikat, „Gazeta Lwowska” 29.11.1918, s. 1.

39 Z. Lasocki, op. cit., s. 38.

40 Ibidem.

41 Z tymczasowego komitetu..., s. 1.

42 M. Przeniosło, op. cit., s. 286.

43 Art. 4 Statutu Komisji Rządzącej dla Galicji i Śląska Cieszyńskiego oraz Górnej Orawy i Spiżu z dnia 10 stycznia 1919 roku (Dz.P.P.P. Nr 7, poz. 106).

44 Art. 1 pkt 1 Dz.P.P.P. z 1919 r. Nr 7, poz. 106. 
przez Komisję Rządzącą wydział wykonawczy, któremu przewodniczył Komisarz Generalny. Aparat administracyjny władz zarówno krajowych, jak i powiatowych miał podlegać wydziałowi wykonawczemu. Dekret z 1919 roku przewidywał wprowadzenie jednolitego systemu administracji terytorialnej, w którym powinno nastąpić „zespolenie” działalności organów administracji krajowej i powiatowej ${ }^{45}$. W sprawach administracyjnych przewidujących trzeci tok instancji, w których zgodnie $\mathrm{z}$ dotychczasowymi przepisami kompetentnym podmiotem był organ centralny w Wiedniu, miało rozstrzygać „właściwe ministerstwo w Warszawie”46. W okresie przejściowym funkcje organu trzeciej instancji wykonywał ,z ramienia Rządu Warszawskiego" powołany wydział wykonawczy ${ }^{47}$. Z dniem powstania Komisji Rządzącej ustawała działalność Polskiej Komisji Likwidacyjnej i Tymczasowego Komitetu Rządzącego ${ }^{48}$.

Nowo utworzony organ ukonstytuował się 28 stycznia 1919 roku na posiedzeniu w Namiestnictwie Galicyjskim ${ }^{49}$. Zorganizowano 15 wydziałów, z czego 7 miało funkcjonować jeszcze w Krakowie. Na Komisarza Generalnego desygnowano Kazimierza Gałeckiego (1863-1941), podczas gdy stanowisko przewodniczącego komisji do czasu przyjazdu komisarza do Lwowa tymczasowo objął Władysław Stesłowicz $(1867-1940)^{50}$. Komisja Rządząca — jak stwierdził K.W. Kumaniecki - ,przestała istnieć, zanim jeszcze zdołała stworzyć sobie jakiś plan działania" ${ }^{51}$. Odbyły się tylko dwa posiedzenia plenarne: w dniach 28 i 29 stycznia 1919 roku. Władzę faktyczną sprawował przewodniczący komisji z wydziałem wykonawczym. Realizacja zadań, które postawiono przed komisją, była $\mathrm{w}$ poważnym stopniu utrudniona ze względu na toczące się walki polsko-ukraińskie, brak żywności czy problemy natury sanitarnej i zdrowotnej ${ }^{52}$. W tej sytuacji komisja nie była w stanie podjąć realnej działalności. Reskryptem prezydium namiestnictwa z dnia 6 marca 1919 roku w miejsce komisarzy Polskiej Komisji Likwidacyjnej przywrócono starostów ${ }^{53}$. Następnego dnia Rada Ministrów, podejmując decyzję o unifikacji administracji państwa, wydała rozporządzenie

\footnotetext{
45 Art. 2 Dz.P.P.P. z 1919 r. Nr 7, poz. 106.

46 Art. 3 Dz.P.P.P. z 1919 r. Nr 7, poz. 106.

47 Ibidem.

48 Art. 9 Dz.P.P.P. z 1919 r. Nr 7, poz. 106.

49 M. Przeniosło, op. cit., s. 287.

50 Ibidem, s. 289.

51 K.W. Kumaniecki, op. cit., s. 130.
}

52 Znamienne w tym względzie były słowa Leonarda Stahla (1866-1929), który w przemówieniu z przyjęcia Generalnego Delegata Rządu dla Galicji stwierdzał: „Wobec trwającej ciągle walki nasza część Komisji prócz zadań ogólnego charakteru administracyjnego i prawodawczego — miała także do rozwiązania i załatwienia całe szeregi zagadnień i spraw wynikłych właśnie ze stanu wojny i konieczności z nią związanych" — Z przyjęcia P. Delegata generalnego Rządu dr. Gałeckiego. Przemówienie dr. Stahla, Lwów 29 marca 1919, „Gazeta Lwowska” 30.031919, s. 1. Por. M. Przeniosło, op. cit., s. 292.

53 Reskrypt Prezydium Namiestnictwa Galicyjskiego z dnia 6 marca 1919 roku, L. 226/pr. (niepublikowany), cyt. za: K.W. Kumaniecki, op. cit., s. 130-131. 
w przedmiocie administracji państwowej w Galicji, znosząc Komisję Rządzącą i powołując Generalnego Delegata Rządu dla Galicji, którym został Kazimierz Gałecki ${ }^{54}$.

Pozycja prawno-ustrojowa generalnego delegata odpowiadała statusowi organu administracji ogólnej. W zakresie ,administracji politycznej” został wyposażony w kompetencje, które przysługiwały Namiestnikowi Galicji ${ }^{55}$. Sprawował „ogólne kierownictwo i kontrolę" w stosunku do tych działów, które nie zostały dotychczas przejęte przez Radę Ministrów. W związku z tym w zakresie administracji rolnictwa, aprowizacji, robót publicznych, kultury i sztuki oraz przemysłu i handlu właściwe ministerstwa miały w porozumieniu z przedstawicielem rządu w Galicji ustanowić swoich delegatów ${ }^{56}$. Przyznane generalnemu delegatowi rządu środki prawne o charakterze koordynacyjnym w stosunku do wskazanych działów administracji były sukcesywnie ograniczane wraz z tworzeniem przez ministerstwa własnych struktur administracji terytorialnej lub dewolucją kompetencji przez samych ministrów ${ }^{57}$. Przy delegacie rządu funkcjonowała jako organ opiniodawczy rada przyboczna, składająca się z 15 członków wyznaczanych przez stronnictwa polityczne, które były reprezentowane w Sejmie przez posłów z Galicji ${ }^{58}$. Z uwagi na to, że Komisja Rządząca nie przeprowadziła reform w kierunku wprowadzenia zasady jednolitego systemu administracji terytorialnej, prawodawca ponownie wyartykułował obowiązek zespolenia ,agend poszczególnych władz samorządnych i państwowych w myśl wskazówek Rządu"59.

Po zniesieniu Sejmu i Wydziału Krajowego mocą ustawy z dnia 30 stycznia 1920 roku ustanowiono Tymczasowy Wydział Samorządowy, który do momentu wprowadzenia jednolitego systemu administracji terytorialnej w Polsce przejął

54 Rozporządzenie Rady Ministrów z dnia 7 marca 1919 roku w przedmiocie administracji państwowej w Galicji (Dz.P.P.P. Nr 24, poz. 240). „Mam przekonanie, że przy poparciu Rządu warszawskiego i powołanych czynników uda mi się rozwiązać wszystkie problemy należące do mego zakresu działalności, utrzymać ład i porządek, zaspokoić bieżące aktualne potrzeby i że będę mógł z przekonaniem spełnionego obowiązku zdać rachunek z mej działalności” — Objęcie urzędowania przez P. Delegata generalnego dr. Gateckiego we Lwowie, „Kurier Lwowski” 29.03.1919, s. 1.

55 Art. 2 Dz.P.P.P. z 1919 r. Nr 24, poz. 240.

56 Ibidem.

57 Por. m.in. Rozporządzenie Rady Ministrów z dnia 18 kwietnia 1919 roku (M.P. Nr 98); rozporządzenie Ministra Przemysłu i Handlu z dnia 12 maja 1919 roku w przedmiocie przejęcia Wydziału Górniczego b. Komisji Rządzącej w Krakowie, postanowionego uchwałą Rady Ministrów z dnia 7 maja 1919 roku (M.P. Nr 108); rozporządzenie Ministra Przemysłu i Handlu z dnia 1 kwietnia 1919 roku w przedmiocie przejęcia Wydziału dla Przemysłu, Rękodzieł i Handlu Komisji Rządzącej oraz Sekcji III Krajowego Urzędu Odbudowy, w myśl uchwały Rady Ministrów z dnia 13 marca 1919 roku (M.P. Nr 78); rozporządzenie wykonawcze Ministra Rolnictwa i Dóbr Państwowych z dnia 19 maja 1919 roku w przedmiocie utworzenia Zarządu Okręgowego Dóbr Państwowych we Lwowie (M.P. Nr 115).

58 Art. 3 Dz.P.P.P. z 1919 r. Nr 24, poz. 240.

59 Art. 4 Dz.P.P.P. z 1919 r. Nr 24, poz. 240.

Studia nad Autorytaryzmem i Totalitaryzmem 41, nr 4, 2019

(C) for this edition by CNS 
zarząd majątkiem organów samorządowych ${ }^{60}$. Przewodniczącym wydziału został tymczasowo generalny delegat rządu ${ }^{61}$.

Zwieńczeniem ewolucji ustrojowej administracji rządowej było rozszerzenie z dniem 23 grudnia 1920 roku przepisów ustawy tymczasowej z 1919 roku na nowo utworzone na ziemiach byłego Królestwa Galicji i Lodomerii z Wielkim Księstwem Krakowskiem województwa: krakowskie, lwowskie, stanisławowskie i tarnopolskie, które wprowadzały obowiązujące już na terenach byłego Królestwa Kongresowego zasady organizacji władzy administracji ogólnej ${ }^{62}$.

$\mathrm{Na}$ terenach Śląska Cieszyńskiego ${ }^{63}$ proces tworzenia struktur polskiej administracji terytorialnej był związany z ukonstytuowaniem się 19 października 1918 roku Rady Narodowej, której zadaniem było, dążąc „do ostatecznego przeprowadzenia nowych porządków w polskich obszarach Austrii w myśl manifestu cesarskiego i warunków Wilsona, strzec interesów ludności polskiej Księstwa Cieszyńskiego i utrzymywać styczność z obecnymi władzami państwowymi”"64. Utworzenie Rady było efektem porozumienia przywódców Związku Śląskich Katolików, Polskiego Zjednoczenia Narodowego i Polskiej Partii Socjalno-Demokratycznej dla Galicji i Śląska, którego celem miało być przejęcie od Austro-Węgier Księstwa Cieszyńskiego w imieniu odradzającej się Rzeczypospolitej ${ }^{65}$. Do organu weszło po siedmiu reprezentantów wskazanych partii i jeden przedstawiciel Związku Społeczno-Narodowego ${ }^{66}$. Prezydium tworzyło trzech prezydentów: ks. Józef Londzin (1862-1929), Tadeusz Reger (1872-1938) i Jan Michejda (1853-1927); funkcję sekretarza objął Paweł Bobek (1883-1945) ${ }^{67}$.

60 Art. 4 ustawy z dnia 30 stycznia 1920 roku o zniesieniu Sejmu i Wydziału Krajowego b. Królestwa Galicji i Lodomerii z Wielkim Księstwem Krakowskiem (Dz.U. Nr 11, poz. 61).

61 Art. 5 Dz.U. z 1920 r. Nr 11, poz. 61.

62 Art. 1 ustawy z dnia 3 grudnia 1920 roku o tymczasowej organizacji władz administracyjnych II instancji (województw) na obszarze b. Królestwa Galicji i Lodomerii z W. Ks. Krakowskiem oraz na wchodzących w skład Rzeczypospolitej Polskiej obszarach Spisza i Orawy (Dz.U. Nr 117, poz. 768).

63 Księstwo Cieszyńskie było częścią tak zwanego Śląska Austriackiego, który jako kraj koronny miał własny sejm i namiestnika. Księstwo liczyło około 427 tysięcy mieszkańców, w tym blisko 234 tysięcy stanowili Polacy. Por. B. Cybulski, Rada Narodowa Księstwa Cieszyńskiego 1918-1920, Opole 1980, s. 9.

${ }^{64}$ Rada Narodowa dla Księstwa Cieszyńskiego, „Kurier Lwowski” 24.10.1918 (wydanie wieczorne), s. 1.

65 B. Cybulski, Rada Narodowa Księstwa Cieszyńskiego. Próby oceny działalności i dokonań, „Pamiętnik Cieszyński” 8, 1994, s. 38. Przedstawiciele stronnictw politycznych Śląska Cieszyńskiego brali także udział w spotkaniach polityków w Krakowie w październiku 1918 roku, które doprowadziły do utworzenia Polskiej Komisji Likwidacyjnej. Por. Z. Lasocki, op. cit., s. 8.

66 B. Cybulski, Rada Narodowa Księstwa Cieszyńskiego. Próby..., s. 39.

67 Podobne działania podjęła strona czeska, która 28 października 1918 roku utworzyła w Opawie Krajowy Komitet Narodowy na Śląsku i proklamowała 1 listopada 1918 roku objęcie władzy na Śląsku austriackim. Por. H. Karczyńska, Od procesu kształtowania się tożsamości subregionalnej do powstania Rady Narodowej Księstwa Cieszyńskiego, [w:] Rok 1918. Odrodzona Polska w nowej Europie, red. A. Ajnenkiel, Warszawa 1999, s. 208.

Studia nad Autorytaryzmem i Totalitaryzmem 41, nr 4, 2019

(C) for this edition by CNS 
Podczas wiecu pod Domem Narodowym w Cieszynie, który odbył się 27 października 1918 roku w związku z odezwą rady, uchwalono rezolucję za włączeniem Śląska Cieszyńskiego do odradzającej się Rzeczypospolitej ${ }^{68}$. W konsekwencji 30 października 1918 roku Rada Narodowa Księstwa Cieszyńskiego uchwaliła proklamację w sprawie przynależności do państwa polskiego ${ }^{69}$. Jednocześnie nakazano wydziałom gminnym utworzenie $\mathrm{w}$ porozumieniu z ludnością straży obywatelskich, które miały za zadanie utrzymanie bezpieczeństwa i porządku publicznego ${ }^{70}$. Rada Narodowa zawiadomiła rząd w Warszawie oraz ośrodki polskiej władzy we Lwowie i Krakowie o ,zorganizowaniu się i objęciu władzy z ramienia rządu polskiego"71. W kwestii organizacji administracji publicznej przyjęto uchwałę o utrzymaniu dotychczasowych struktur ,administracji państwowej i autonomicznej”, podporządkowując ,wszystkie władze powiatowe i gminne” Radzie Narodowej ${ }^{72}$.

W początkach funkcjonowania Rady Narodowej opracowano dwa projekty organizacji administracji publicznej. Autorami jednego z nich byli: Zofia Kirkor-Kiedroniowa (1872-1952), Leon Wolf (1883-1968) i Dorota Kłuszczyńska (1876-1952) lub Władysław Jeziorski (1882-1934) ${ }^{73}$. Zofia Kirkor-Kiedroniowa była zdania, że „ostateczne połączenie Śląska Cieszyńskiego z Polską nie nastąpi

68 Por. B. Cybulski, Rada Narodowa Księstwa Cieszyńskiego. Próby..., s. 40; J. Szczurek, Z wielkich dni Śląska Cieszyńskiego, cz. 3. Przewrót polityczny i wojskowy wr. 1918, Cieszyn 1928, s. 14.

69 „Rada Narodowa dla Księstwa Cieszyńskiego, opierając się [...] na jednomyślnej woli i zgodzie ludności Śląska, wyrażonej ostatnio na wiecach ludowych w Orłowej, w Boguminie, w Cieszynie, proklamuje uroczyście przynależność państwową Księstwa Cieszyńskiego do wolnej, niepodległej, zjednoczonej Polski i obejmuje nad nim władzę państwową" - Proklamacja przynależności Księstwa Cieszyńskiego do Polski (Dz.Urz. RNKC z 1919 r. Nr 1, poz. 1).

70 Ibidem, s. 2.

71 Obwieszczenie Rady Narodowej Księstwa Cieszyńskiego z dnia 2 listopada 1918 roku w sprawie objęcia i uznania zwierzchniej władzy (Dz.Urz. RNKC z 1919 r. Nr 1, poz. 2).

72 Pkt 3 obwieszczenia Rady Narodowej Księstwa Cieszyńskiego z dnia 2 listopada 1918 roku w sprawie uregulowania stosunków prawnych względem mieszkańców i dotychczasowych władz (Dz.Urz. RNKC z 1919 r. Nr 1, poz. 4).

73 Według wspomnień Zofii Kirkor-Kiedroniowej w skład komisji oprócz niej i Leona Wolfa weszła Dorota Kłuszczyńska. W świetle protokołu z posiedzenia Rady Narodowej z dnia 2 listopada 1918 roku w skład komisji, która przygotowała projekt, miał wejść Władysław Jeziorski, nie zaś Dorota Kłuszczyńska. „Odpowiedni wniosek, uzgodniony z moim mężem, wniosłam na Radę Narodową. [...] Rada przyjęła mój wniosek i dla opracowania go w szczegółach i przedłożenia listy ewentualnych wydziałów wyznaczyła trzech swoich członków: dra Wolfa, p. Kłuszczyńską i mnie. Nazajutrz opracowaliśmy projekt" - Z. z Grabskich Kirkor-Kiedroniowa, Wspomnienia, cz. 2. Ziemia mojego męża, wstępem poprzedził H. Wereszycki, red. A. Szklarska-Lohmannowa, komentarze: M. Stolzmanowa, A. Szklarska-Lohmannowa, Kraków 1988, s. 303-304. „Kiedroniowa wnosi: Rada Narodowa uchwala stworzyć wydziały: polityczny, wewnętrzny, finansów, wojskowy, sprawiedliwości, oświaty, przemysłu i handlu, górnictwa. Rada Narodowa mianuje szefów, a ci w 48 godzin dadzą plan organizacji wydziałów dla zatwierdzenia Rady. [...] Uchwalono: Wniosek rozpatrzy komisja: Kiedroniowa, Jeziorski, Wolf" — Protokół z posiedzenia Rady Narodowej, odbytego dnia 2 listopada 1918 r., Księga Protokołów Rady Narodowej dla Księstwa Cieszyńskiego. Księga I, 
prędko"74. Z tego względu projekt przewidywał powołanie przez Radę Narodową organu administracji rządowej z wydziałami wyodrębnionymi według kryterium resortowego. Proponowano utworzenie wydziałów: spraw wewnętrznych, skarbowego, sprawiedliwości, wojskowego, komunikacji, oświaty, przemysłu, górnictwa i handlu, rolnictwa, aprowizacji, zdrowia publicznego, spraw społecznych i ogólnopolitycznego $^{75}$. Szefowie poszczególnych jednostek resortowych mieli być powoływani przez Radę Narodową. Przewodniczącym powołanego organu był naczelnik wydziału ogólnopolitycznego, który koordynował pracę poszczególnych wydziałów i przedstawiał na forum rady wnioski poszczególnych resortów ${ }^{76}$.

Na szczególną uwagę zasługuje kolejny dokument. Był to Projekt w sprawie przejęcia władz i ich organizacji z chwila zjednoczenia Księstwa Cieszyńskiego z Polska ${ }^{77}$, którego autorem był prawdopodobnie Kazimierz Piątkowski (1873$1942)^{78}$. Projekt stał się przedmiotem prac powołanej w tym celu przez Radę Narodową specjalnej komisji ${ }^{79}$. W świetle założeń tego opracowania Księstwo Cieszyńskie miało status województwa. Rada Narodowa miała zostać przekształcona w Radę Województwa Cieszyńskiego (Ziemi Cieszyńskiej). Była bowiem „ciałem ustawodawczym i rządzącym w okresie przejściowym" ${ }^{80}$. Rada wykonywała

k. 10, [w:] Protokoty posiedzeń plenarnych Rady Narodowej Księstwa Cieszyńskiego (1918-1920), cz. 1, wydali: E. Długajczyk, M. Skrzypek, Cieszyn 2016, s. 113.

74 Z. z Grabskich Kirkor-Kiedroniowa, op. cit., s. 303.

75 Protokót z posiedzenia Rady Narodowej, odbytego dnia 4 listopada 1918 r. Księga Protokołów Rady Narodowej dla Księstwa Cieszyńskiego. Księga I, k. 12v., [w:] Protokoty posiedzeń plenarnych Rady Narodowej Księstwa Cieszyńskiego..., cz. 1, s. 122-123.

76 Ibidem, s. 123.

77 Projekt w sprawie przejęcia władz i ich organizacji z chwila zjednoczenia Księstwa Cieszyńskiego z Polska. Załącznik do Protokołu Rady Narodowej Księstwa Cieszyńskiego z dnia 26 października 1918 r., APC, RNKC, sygn. 27, s. 267-275, [w:] Protokoty posiedzeń plenarnych Rady Narodowej Księstwa Cieszyńskiego (1918-1920), cz. 2. Dokumenty dodatkowe, wydał M. Skrzypek, Cieszyn 2016, Dokument nr 32, s. 55-61.

78 W protokole z posiedzenia Rady Narodowej, które odbyło się 4 listopada 1918 roku odnotowano: „T. Michejda wnosi: Przyjąć projekt Piątkowskiego za podstawę” - Protokół z posiedzenia Rady Narodowej, odbytego dnia 4 listopada 1918 r. Księga Protokołów Rady Narodowej dla Księstwa Cieszyńskiego. Księga I, k. 14, [w:] Protokoły posiedzeń plenarnych Rady Narodowej Księstwa Cieszyńskiego..., cz. 1, s. 124. Kazimierz Piątkowski referował wcześniej ów projekt przed Radą Narodową na posiedzeniu 26 października 1918 roku, podczas którego stwierdzono, ,że należy projekt odbić i dostarczyć go poszczególnym członkom, a potem dopiero odbyć dyskusję ogólną i szczegółową" - Protokół z posiedzenia Rady Narodowej, odbytego dnia 26 października 1918 r. Księga Protokołów Rady Narodowej dla Księstwa Cieszyńskiego. Księga I, k. 3v., [w:] Protokoty posiedzeń plenarnych Rady Narodowej Księstwa Cieszyńskiego..., cz. 1, s. 102.

79 Skład siedmioosobowego komitetu powołanego do prac nad projektem tworzyli: Leon Wolf (1883-1968), Eugeniusz Brzuska (1885-1938), Tadeusz Reger (1872-1938), Jerzy Kantor (1872-1954), Jan Kotas (1878-1954), Paweł Bobek (1883-1945) i Kazimierz Piątkowski (18731942). Por. 1918, 27 października, Cieszyn - Protokół z posiedzenia Rady Narodowej Księstwa Cieszyńskiego (rękopis), KCC, Teki Regera, sygn. 015.009, b.p., [w:] Protokoly posiedzeń plenarnych Rady Narodowej Księstwa Cieszyńskiego..., cz. 2, Dokument nr 4, s. 14.

80 Ibidem, s. 56, pkt II ust. 1. 
kompetencje w zakresie władzy wykonawczej za pośrednictwem zarządu wojewódzkiego (ziemskiego). W ramach tego organu wyodrębniono 10 wydziałów ${ }^{81}$, spośród których szczególną pozycję miał wydział ogólnopolityczny. Na czele tej jednostki stał komisarz zarządu województwa, który jednocześnie występował jako jego przewodniczący. Komisarz kontrolował działalność poszczególnych wydziałów i odpowiadał za wykonywanie postanowień Rady Województwa ${ }^{82}$. Miał pośredniczyć między radą wojewódzką i zarządem a „rządem centralnym

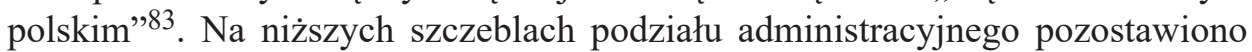
starostwa i gminy polityczne ${ }^{84}$. Projekt określał dość szczegółowo zakres rzeczowy poszczególnych resortów ${ }^{85}$. Wskazane dokumenty — zwłaszcza ze względu na wyjątkową i zmienną sytuację polityczno-prawną Śląska Cieszyńskiego ostatecznie nie weszły w życie ${ }^{86}$.

W nawiązaniu do ustaleń delegacji Rady Narodowej z rządem polskim w Warszawie 18 grudnia 1918 roku mocą rozporządzenia utworzono „prowizoryczny” Rząd Krajowy Księstwa Cieszyńskiego, znosząc dotychczasowy dualistyczny podział administracji na państwową (Rząd Krajowy w Opawie) i autonomiczną (Wydział Krajowy w Opawie) ${ }^{87}$. Powołany podmiot miał objąć zwierzchnictwo nad wszystkimi organami, które dotąd zgodnie z przepisami austriackimi podlegały szefowi administracji politycznej (ogólnej) w Opawie, „względnie Rządowi i Wydziałowi krajowemu w mieście Bielsku i w starostwie Bielskim, Cieszyńskim i Frysztackim" ${ }^{88}$. Zgodnie z art. 10 rozporządzenia status władz administracji ogólnej pierwszej instancji miał funkcjonować na dotychczasowych zasadach.

81 Wyróżniono 10 wydziałów zarządu województwa: spraw wewnętrznych, skarbowy, sprawiedliwości, wojskowy, komunikacji i robót publicznych, oświaty, wyżywienia, rolnictwa i domen, przemysłu i handlu, ogólnopolityczny — ibidem, s. 57, pkt III ust. 3.

82 Ibidem, s. 56-57, pkt III ust. 1.

83 Ibidem, s. 61, pkt IV lit. J.

84 Ibidem, s. 55, pkt I lit. B.

85 Por. B. Cybulski, Rada Narodowa Księstwa Cieszyńskiego. Próby..., s. 44; idem, Rada Narodowa Księstwa Cieszyńskiego 1918-1920..., s. 41 n.; A. Tarnowska, op. cit., s. 43.

86 Bogdan Cybulski wyróżnił kilka zdarzeń natury polityczno-prawnej, które miały istotny wpływ status Śląska Cieszyńskiego: powstanie Rady Narodowej (19 października 1918 roku), przejęcie władzy przez Radę Narodową (1 listopada 1918 roku), spotkanie delegacji Rady Narodowej z rządem polskim (25 listopada 1918 roku), wojna czesko-polska (23 stycznia-3 lutego 1919 roku), przejęcie władzy przez Komisję Plebiscytową (3 lutego 1919 roku); decyzja o podziale Śląska Cieszyńskiego (28 lipca 1919 roku) - B. Cybulski, Rada Narodowa Księstwa Cieszyńskiego. Próby..., s. 45.

87 Art. 1 i 2 rozporządzenia Rady Narodowej Księstwa Cieszyńskiego z dnia 18 grudnia 1918 roku w sprawie utworzenia tymczasowego Rządu krajowego w Cieszynie i objęcia przezeń agend dotychczasowego rządu krajowego w Opawie — zatwierdzone reskryptem Rządu polskiego w Warszawie z dnia 14 stycznia 1919 roku, 1. 418, 19 (Dz.Urz. RNKC Nr 2, poz. 39). Por. B. Cybulski, Geneza Rządu Krajowego Księstwa Cieszyńskiego (grudzień 1918-styczeń 1919 r.), „Czasopismo Prawno-Historyczne" 28, 1976, nr 2, s. 195-209.

88 Spod władzy administracyjnej „Rządu Krajowego” wyłączono gminy: Orłowa, Łazy, Sucha Średnia, Sucha Dolna, Pietwałd i Dziećmorowice — art. 3 Dz.Urz. RNKC z 1919 r. Nr 2, poz. 39. 
Na uwagę zasługuje stosunkowo szybkie przejęcie przez władze polskie administracji szkolnej ${ }^{89}$. Ministerstwo Wyznań Religijnych i Oświecenia Publicznego w Warszawie, obejmując zwierzchnictwo nad administracją szkolną na terenie Śląska Cieszyńskiego, przekazało tymczasowo kompetencje należące dotychczas do Śląskiej Rady Szkolnej Krajowej i Śląskiego Wydziału Krajowego w Opawie utworzonej w tym celu Komisji Szkolnej Księstwa Cieszyńskiego ${ }^{90}$.

Sytuacja na Śląsku Cieszyńskim ulegała zmianie w wyniku najazdu wojsk czeskich 23 stycznia 1919 roku $^{91}$, wobec czego Rada Narodowa ewakuowała się do Krakowa, a następnie do Bielska, gdzie w niepełnym składzie nadal zbierała się na posiedzenia ${ }^{92}$. Zgodnie z zawartą 3 lutego 1919 roku w Paryżu umową do Cieszyna miała zostać wysłana Komisja Międzysojusznicza, a właściwość terytorialna Rady Narodowej została faktycznie ograniczona do rzeki Olzy, która stanowiła linię demarkacyjną ${ }^{93}$. Ostatecznie postanowiono o przeprowadzeniu na terenie Śląska Cieszyńskiego plebiscytu. Komisja Plebiscytowa 4 lutego 1920 roku podjęła decyzję o utworzeniu prefektury i Komisji Administracyjnej dla Zagłębia Karwińskiego ${ }^{94}$. Tym samym Rada Narodowa utraciła kompetencje prawotwórcze i wykonawcze. Warto jednak zwrócić uwagę, że prefektem dla wschodniej części Śląska Cieszyńskiego został Zygmunt Żurawski (1873-1962), starosta cieszyński i późniejszy komisarz rządowy ${ }^{95}$. Ostatecznie decyzją Rady Ambasadorów z 28 lipca 1920 roku dokonano podziału Śląska Cieszyńskiego, w wyniku czego Polsce przypadło starostwo bielskie oraz część cieszyńskiego i frysztackiego 96 .

89 „Niniejszym zawiadamiam, że Pan Karol Opuszyński, wizytator Ministerstwa Wyznań Religijnych i Oświecenia Publicznego w Warszawie, otrzymał polecenie udać się na Śląsk Cieszyński celem przejęcia w imieniu Ministerstwa całego szkolnictwa" - Informacja Ministra Wyznań Religijnych i Oświecenia Publicznego o wysłaniu na Śląsk Cieszyński swojego delegata w celu przejęcia miejscowego szkolnictwa, APC, RNKC, sygn. 19, s. 299, [w:] Protokoły posiedzeń plenarnych Rady Narodowej Księstwa Cieszyńskiego..., cz. 2, Dokument nr 14, s. 32.

90 § 2 rozporządzenia Rządu Polskiego w Warszawie z dnia 25 listopada 1918 roku dotyczącego tymczasowej administracji szkolnej Księstwa Cieszyńskiego (Dz.Urz. RNKC z 1919 r. Nr 1, s. 12).

91 „Początek wojny zaznaczyli Czesi już około godziny 6-tej rano 23 stycznia 1919 r. aresztowaniem polskich działaczy" - F.K. Latinik, Walka o Ślask Cieszyński w r. 1919, Cieszyn 1934, s. 44. Por. S. Kutrzeba, Polska Odrodzona (1914-1928), Warszawa 1928, s. 93 n.

92 Por. Protokoty posiedzeń Rady Narodowej Księstwa Cieszyńskiego odbytych w Krakowie $w$ dniach 28, 29, 30, 31 stycznia 1919 r. oraz z dnia 1, 5, 6, 7, 10, 14, 15, 16 lutego 1919 r. Ksiega Protokotów Rady Narodowej dla Księstwa Cieszyńskiego. Księga I, k. 83v.-92, [w:] Protokoły posiedzeń plenarnych Rady Narodowej Księstwa Cieszyńskiego..., cz. 1, s. 210-230.

93 Ugoda paryska z 3. Lutego 1919 r., [w:] Kwestia cieszyńska. Zbiór dokumentów z okresu walki o Ślask Cieszyński 1918-1920, zestawił W. Dąbrowski, Katowice 1923, s. 13.

94 Por. B. Cybulski, Rada Narodowa Księstwa Cieszyńskiego. Próby..., s. 49-50.

95 M. Skrzypek, Zygmunt Żurawski (1873-1962) — polityk południowo-zachodnich kresów II Rzeczypospolitej, „Wieki Stare i Nowe” 2012, tom specjalny — Ludzie i elity pogranicza, red. M. Filc, R. Kaczmarek, s. 202.

96 K. Nowak, Z problemów Śląska Cieszyńskiego w „okresie przejściowym” (sierpień 1920czerwiec 1922), „Pamiętnik Cieszyński” 8, 1994, s. 77; 1920 lipiec 28, Paryż — Decyzja Kon- 
Jeszcze przed ogłoszeniem wyroku rady Sejm Ustawodawczy 15 lipca 1920 roku uchwalił statut organiczny województwa śląskiego, zgodnie z którym nowa jednostka podziału administracyjnego miała objąć wszystkie ziemie przyznane państwu polskiemu na Śląsku Cieszyńskim ${ }^{97}$. W świetle art. 40 statutu organicznego do momentu faktycznego objęcia zwierzchnictwa przez państwo polskie władzę na tym terenie miała sprawować Komisja Tymczasowa z komisarzem rządowym i jego zastępcą, pochodzącymi z nominacji Naczelnika Państwa, oraz pięcioma członkami, których powoływała Rada Ministrów ${ }^{98}$. W związku z tym Rada Narodowa Księstwa Cieszyńskiego na ostatnim posiedzeniu 4 sierpnia 1920 roku podjęła decyzję o rozwiązaniu, stając się najdłużej funkcjonującym spośród wszystkich polskich rządów dzielnicowych organem władzy odradzającej się Rzeczypospolitej.

Przed dwudziestoma miesiącami rozpoczęliśmy budowę państwowości polskiej. Pracę przerwał najazd czeski, po którym praca nasza była tylko na części terenów. Zamykamy byt Rady Narodowej w chwili apatii, upadku wywołanego słabością państwa. Ugiąć się musimy, ale $\mathrm{z}$ tą pewnością, że odbijemy to, co nam zabrano. [...] Rozejdźmy się z podniesionym czołem. Zrobiliśmy swoje $\mathrm{e}^{99}$.

$* * *$

Przebieg procesu tworzenia systemu polskiej administracji w 1918 roku na obszarze byłego zaboru austriackiego miał swoją specyfikę. Przede wszystkim należy zwrócić uwagę na strukturę, którą stworzyła Polska Komisja Likwidacyjna, realizująca funkcję administrowania przy pomocy wydziałów resortowych na czele z kierownikami. Konstrukcję ustrojową administracji terytorialnej oparto na zasadzie monizmu i koncepcji administracji ogólnej. Dotychczasowe organy samorządu terytorialnego miały pełnić funkcję opiniodawczą. W budowie organów administracji terytorialnej dominował system monokratyczny. Inne rozwiązania przyjęto na obszarze Galicji Wschodniej, gdzie władzę pierwotnie objął Tymczasowy Komitet Rządzący, w ramach którego wyodrębniono referaty o charakterze resortowym. W wyniku rozmów członków komitetu z Polską Komisją Likwidacyjną, działając w porozumieniu z rządem polskim, powołano Komisję Rządzącą.

ferencji Ambasadorów w sprawie Śląska Cieszyńskiego, Spisza i Orawy, [w:] Powstanie II Rzeczypospolitej. Wybór dokumentów 1866-1925, red. H. Janowska, T. Jędruszczak, Warszawa 1984, s. $580-585$.

97 Art. 1 ust. 1 Ustawy Konstytucyjnej z dnia 15 lipca 1920 roku zawierającej statut organiczny Województwa Śląskiego (Dz.U. Nr 73, poz. 497). Por. J. Przygodzki, Koncepcje podziału terytorialnego Rzeczypospolitej Polskiej w latach 1918-1921, [w:] Na szlakach niepodległej. Polska myśl polityczna i prawna w latach 1918-1939, red. M. Marszał, M. Sadowski, Wrocław 2009, s. 299.

98 Art. 40 ust. 1 Dz.U. z 1920 r. Nr 73, poz. 497.

99 Protokót z posiedzenia Rady Narodowej, odbytego dnia 4 sierpnia 1920 r. Księga Protokołów Rady Narodowej dla Księstwa Cieszyńskiego, Księga II, k. 61v., k. 63v., [w:] Protokoły posiedzeń plenarnych Rady Narodowej Księstwa Cieszyńskiego..., cz. 1, s. 520, 524. 
Realizację zadań z zakresu administracji publicznej powierzono wydziałowi wykonawczemu na czele z komisarzem generalnym, któremu podporządkowano aparat administracyjny władz zarówno krajowych, jak i powiatowych. System administracji terytorialnej w świetle dekretu konstytuującego Komisję Rządzącą oparto na zasadzie jednolitości. Po zniesieniu Komisji Rządzącej utworzono stanowisko Generalnego Delegata Rządu dla Galicji, którego status został oparty na koncepcji władzy administracji ogólnej. Pełnił on jednocześnie funkcję przewodniczącego Tymczasowego Wydziału Samorządowego. Delegat generalny był ostatnim organem tymczasowym przed rozciągnięciem na obszar Galicji systemu administracji terytorialnej, który obowiązywał na terenach byłego Królestwa Kongresowego. Na obszarze Śląska Cieszyńskiego zasadniczo utrzymano dotychczasową strukturę administracji publicznej, podporządkowując ją Radzie Narodowej. Należy jednak zwrócić uwagę na przygotowane w ramach rady dwa projekty organizacji administracji publicznej. Pierwszy z nich zakładał utworzenie do czasu włączenia Śląska Cieszyńskiego do Rzeczypospolitej kolegialnego organu administracji rządowej z wydziałami resortowymi, którymi kierowali naczelnicy powoływani przez Radę Narodową. Drugi z projektów przewidywał przyznanie Księstwu Cieszyńskiemu statusu województwa z radą i zarządem wojewódzkim. Projektowany system administracji terytorialnej oparto na modelu austriackim ${ }^{100}$.

Organizacja administracji terytorialnej tworzona w warunkach szczególnego zagrożenia bezpieczeństwa państwa i budowy tymczasowych struktur administracji miała przede wszystkim sprzyjać unifikacji ustrojowej i hołdować zasadzie efektywności. $Z$ tego względu w okresie przejściowym co do zasady rezygnowano z zasady dualizmu administracji rządowej i samorządowej, przenosząc ciężar administrowania na jednoosobowe organy administracji rządowej. Przyjęte rozwiązania ustrojowo-prawne pozwalały szybciej reagować na dynamikę zagrożeń i skuteczniej realizować zadania nadkładane w tym zakresie na administrację publiczną ${ }^{101}$. Rolą administracji miało być w szczególności tworzenie adekwatnych warunków do przetrwania i rozwoju organizacji, jaką było odradzające się państwo polskie.

100 Por. J. Kostrubiec, Der Einfluss des deutschen Gedankens auf doktrinäre Konzepte und normative Grundsätze der kommunalen Selbstverwaltung in der Zweiten Republik, [w:] Samorzad terytorialny w Polsce $i$ w Niemczech. Kommunale Selbstverwaltung in Polen und in Deutschland, red. M.E. Geis et al., Warszawa 2015, s. 137-138.

101 Por. M. Karpiuk, Zadania i kompetencje zespolonej administracji rządowej $w$ sferze bezpieczeństwa narodowego Rzeczypospolitej Polskiej. Aspekty materialne i formalne, Warszawa 2013, s. 114. 


\section{Bibliografia}

\section{Źródła drukowane}

1918, 27 października, Cieszyn - Protokół z posiedzenia Rady Narodowej Księstwa Cieszyńskiego (rękopis), KCC, Teki Regera, sygn. 015.009, b.p., [w:] Protokoly posiedzeń plenarnych Rady Narodowej Księstwa Cieszyńskiego (1918-1920), cz. 2. Dokumenty dodatkowe, wydał M. Skrzypek, Cieszyn 2016.

1920 lipiec 28, Paryż - Decyzja Konferencji Ambasadorów w sprawie Śląska Cieszyńskiego, Spisza i Orawy, [w:] Powstanie II Rzeczypospolitej. Wybór dokumentów 1866-1925, red. H. Janowska, T. Jędruszczak, Warszawa 1984.

Informacja Ministra Wyznań Religijnych i Oświecenia Publicznego o wysłaniu na Śląsk Cieszyński swojego delegata w celu przejęcia miejscowego szkolnictwa, APC, RNKC, sygn. 19, s. 299, [w:] Protokoły posiedzeń plenarnych Rady Narodowej Księstwa Cieszyńskiego (1918-1920), cz. 2. Dokumenty dodatkowe, wydał M. Skrzypek, Cieszyn 2016.

Projekt $w$ sprawie przejęcia władz i ich organizacji z chwila zjednoczenia Księstwa Cieszyńskiego z Polska, Załącznik do Protokołu Rady Narodowej Księstwa Cieszyńskiego z dnia 26 października 1918 r., APC, RNKC, sygn. 27, [w:] Protokoty posiedzeń plenarnych Rady Narodowej Księstwa Cieszyńskiego (1918-1920), cz. 2. Dokumenty dodatkowe, wydał M. Skrzypek, Cieszyn 2016.

Protokoły posiedzeń Rady Narodowej Księstwa Cieszyńskiego odbytych w Krakowie w dniach 28, 29, 30, 31 stycznia 1919 r. oraz z dnia 1, 5, 6, 7, 10, 14, 15, 16 lutego 1919 r. Księga Protokołów Rady Narodowej dla Księstwa Cieszyńskiego. Księga I, [w:] Protokoły posiedzeń plenarnych Rady Narodowej Księstwa Cieszyńskiego (1918-1920), cz. 1, wydali E. Długajczyk, M. Skrzypek, Cieszyn 2016.

Protokót z posiedzenia Rady Narodowej Księstwa Cieszyńskiego (rękopis), odbytego dnia 27 października 1918 r., KCC, Teki Regera, sygn. 015.009, brak paginacji, [w:] Protokoty posiedzeń plenarnych Rady Narodowej Księstwa Cieszyńskiego (1918-1920), cz. 2. Dokumenty dodatkowe, wydał M. Skrzypek, Cieszyn 2016.

Protokół z posiedzenia Rady Narodowej, odbytego dnia 26 października 1918 r. Księga Protokołów Rady Narodowej dla Księstwa Cieszyńskiego. Księga I, k. 3v., [w:] Protokoły posiedzeń plenarnych Rady Narodowej Księstwa Cieszyńskiego (1918-1920), cz. 1, wydali E. Długajczyk, M. Skrzypek, Cieszyn 2016.

Protokól z posiedzenia Rady Narodowej, odbytego dnia 2 listopada 1918 r. Księa Protokołów Rady Narodowej dla Księstwa Cieszyńskiego. Księga I, [w:] Protokoty posiedzeń plenarnych Rady Narodowej Księstwa Cieszyńskiego (1918-1920), cz. 1, wydali E. Długajczyk, M. Skrzypek, Cieszyn 2016.

Protokót z posiedzenia Rady Narodowej, odbytego dnia 4 listopada 1918 r. Księga Protokołów Rady Narodowej dla Księstwa Cieszyńskiego. Księga I, k. 12v., [w:] Protokoły posiedzeń plenarnych Rady Narodowej Księstwa Cieszyńskiego (1918-1920), cz. 1, wydali E. Długajczyk, M. Skrzypek, Cieszyn 2016.

Protokót z posiedzenia Rady Narodowej, odbytego dnia 4 listopada 1918 r. Księga Protokołów Rady Narodowej dla Księstwa Cieszyńskiego. Księga I, k. 14, [w:] Protokoły posiedzeń plenarnych Rady Narodowej Księstwa Cieszyńskiego (1918-1920), cz. 1, wydali E. Długajczyk, M. Skrzypek, Cieszyn 2016.

Protokół z posiedzenia Rady Narodowej, odbytego dnia 4 sierpnia 1920 r. Księga Protokołów Rady Narodowej dla Księstwa Cieszyńskiego. Księga II, k. 61v., k. 63v., [w:] Protokoły posiedzeń plenarnych Rady Narodowej Księstwa Cieszyńskiego (1918-1920), cz. 1, wydali E. Długajczyk, M. Skrzypek, Cieszyn 2016. 
Ugoda paryska z 3. Lutego 1919 r., [w:] Kwestia cieszyńska. Zbiór dokumentów z okresu walki o Śląsk Cieszyński 1918-1920, zestawił W. Dąbrowski, Katowice 1923.

\section{Akty normatywne}

Obwieszczenie Rady Narodowej Księstwa Cieszyńskiego z dnia 2 listopada 1918 roku w sprawie objęcia i uznania zwierzchniej władzy (Dz.Urz. RNKC z 1919 r. Nr 1, poz. 2).

Obwieszczenie Rady Narodowej Księstwa Cieszyńskiego z dnia 2 listopada 1918 roku w sprawie uregulowania stosunków prawnych względem mieszkańców i dotychczasowych władz (Dz. Urz. RNKC z 1919 r. Nr 1, poz. 4).

Postanowienie Rady Regencyjnej Królestwa Polskiego z dnia 31 października 1918 roku (M.P. Nr 191). Proklamacja przynależności Księstwa Cieszyńskiego do Polski (Dz.Urz. RNKC z 1919 r. Nr 1, poz. 1). Rozporządzenie Ministra Przemysłu i Handlu z dnia 1 kwietnia 1919 roku w przedmiocie przejęcia Wydziału dla Przemysłu, Rękodzieł i Handlu Komisji Rządzącej oraz Sekcji III Krajowego Urzędu Odbudowy, w myśl uchwały Rady Ministrów z dnia 13 marca 1919 roku (M.P. Nr 78).

Rozporządzenie Ministra Przemysłu i Handlu z dnia 12 maja 1919 roku w przedmiocie przejęcia Wydziału Górniczego b. Komisji Rządzącej w Krakowie, postanowionego uchwałą Rady Ministrów z dnia 7 maja 1919 roku (M.P. Nr 108).

Rozporządzenie Rady Ministrów z dnia 18 kwietnia 1919 roku (M.P. Nr 98).

Rozporządzenie Rady Ministrów z dnia 7 marca 1919 roku w przedmiocie administracji państwowej w Galicji (Dz.P.P.P. Nr 24, poz. 240).

Rozporządzenie Rady Narodowej Księstwa Cieszyńskiego z dnia 18 grudnia 1918 roku w sprawie utworzenia tymczasowego Rządu krajowego w Cieszynie i objęcia przezeń agend dotychczasowego rządu krajowego w Opawie — zatwierdzone reskryptem Rządu polskiego w Warszawie z dnia 14 stycznia 1919 roku, 1. 418, 19 (Dz.Urz. RNKC Nr 2, poz. 39).

Rozporządzenie Rządu Polskiego w Warszawie z dnia 25 listopada 1918 roku dotyczące tymczasowej administracji szkolnej Księstwa Cieszyńskiego (Dz.Urz. RNKC Nr 1, s. 12).

Rozporządzenie Wydziału Administracyjnego PKL z dnia 21 listopada 1918 roku, L. 128/Adm. (Dz.R. PKL Cz. I, L. 13).

Rozporządzenie wykonawcze Ministra Rolnictwa i Dóbr Państwowych z dnia 19 maja 1919 roku w przedmiocie utworzenia Zarządu Okręgowego Dóbr Państwowych we Lwowie (M.P. Nr 115).

Statut Komisji Rządzącej dla Galicji i Śląska Cieszyńskiego oraz Górnej Orawy i Spiżu z dnia 10 stycznia 1919 roku (Dz.P.P.P. Nr 7, poz. 106).

Ustawa Konstytucyjna z dnia 15 lipca 1920 roku zawierająca statut organiczny Województwa Śląskiego (Dz.U. Nr 73, poz. 497).

Ustawa z dnia 30 stycznia 1920 roku o zniesieniu Sejmu i Wydziału Krajowego b. Królestwa Galicji i Lodomerii z Wielkim Księstwem Krakowskiem (Dz.U. Nr 11, poz. 61).

Ustawa z dnia 3 grudnia 1920 roku o tymczasowej organizacji władz administracyjnych II instancji (województw) na obszarze b. Królestwa Galicji i Lodomerii z W. Ks. Krakowskiem oraz na wchodzących w skład Rzeczypospolitej Polskiej obszarach Spisza i Orawy (Dz.U. Nr 117, poz. 768 ).

\section{Opracowania}

Ajnenkiel A., Od rządów ludowych do przewrotu majowego. Zarys dziejów politycznych Polski 1918-1926, Warszawa 1977.

Bąkowski K., Kronika Krakowa z lat 1918-1923 z ilustracjami, Kraków 1925.

Bobrzyński M., Wskrzeszenie Państwa Polskiego. Szkic historyczny, t. 2. 1918-1923, Kraków 1925.

Studia nad Autorytaryzmem i Totalitaryzmem 41, nr 4, 2019

(C) for this edition by CNS 
Bosiacki A., Od naturalizmu do etatyzmu. Doktryny samorząu terytorialnego Drugiej Rzeczpospolitej 1918-1939, Warszawa 2006.

Bożek M., Ksztalt ustawodawstwa stanów nadzwyczajnych $w$ okresie odbudowy państwowości (1918-1921), „Studia Iuridica Lublinensia” 16, 2011.

Cybulski B., Geneza Rządu Krajowego Księstwa Cieszyńskiego (grudzień 1918-styczeń 1919 r.), „Czasopismo Prawno-Historyczne” 28, 1976, nr 2.

Cybulski B., Rada Narodowa Księstwa Cieszyńskiego 1918-1920, Opole 1980.

Cybulski B., Rada Narodowa Księstwa Cieszyńskiego. Próby oceny działalności i dokonań, „Pamiętnik Cieszyński” 8, 1994.

Dąbrowski P., Rozpolitykowane miasto. Ustrój polityczny państwa w koncepcjach polskich ugrupowań działajacych w Wilnie w latach 1918-1939, Gdańsk 2012.

Głąbiński S., Odkąd Polska jest państwem niepodległym?, Warszawa 1931.

Hausner A.W., Listopad 1918. W dziesiąta rocznicę, Lwów 1928.

Hoffman I., The changes of the roles of the Hungarian counties: Towards a one and a half-tier system?, „Lex Localis — Journal Of Local Self-Government” 12, 2014, nr 3, DOI: 10.4335/12.3.393-415(2014).

Karczyńska H., Od procesu ksztattowania się tożsamości subregionalnej do powstania Rady Narodowej Księstwa Cieszyńskiego, [w:] Rok 1918. Odrodzona Polska w nowej Europie, red. A. Ajnenkiel, Warszawa 1999.

Karpiuk M., Zadania i kompetencje zespolonej administracji rzadowej w sferze bezpieczeństwa narodowego Rzeczypospolitej Polskiej. Aspekty materialne i formalne, Warszawa 2013.

Kirkor-Kiedroniowa Z. z Grabskich, Wspomnienia, cz. 2. Ziemia mojego męża, wstępem poprzedził H. Wereszycki, red. A. Szklarska-Lohmannowa, komentarze: M. Stolzmanowa, A. Szklarska-Lohmannowa, Kraków 1988.

Komunikat, „Gazeta Lwowska” 29.11.1918.

Kostrubiec J., Administracja ogólna w myśli prawniczej Drugiej Rzeczypospolitej, Warszawa 2019.

Kostrubiec J., Der Einfluss des deutschen Gedankens auf doktrinäre Konzepte und normative Grundsätze der kommunalen Selbstverwaltung in der Zweiten Republik, [w:] Samorzad terytorialny w Polsce $i$ w Niemczech. Kommunale Selbstverwaltung in Polen und in Deutschland, red. M.E. Geis, G. Grabarczyk, J. Kostrubiec, J. Paśnik, Th.I. Schmidt, Warszawa 2015.

Kumaniecki K.W., Ustrój państwowych władz administracyjnych na ziemiach Polski, Kraków 1920.

Kutrzeba S., Odbiór Galicji, „Głos Narodu” 30.10.1918.

Kutrzeba S., Polska Odrodzona (1914-1928), Warszawa-Kraków-Lublin-Łódź-Paryż-Poznań-WilnoZakopane 1928.

Lasocki Z., Wspomnienia szefa administracji P.K.L. i K.Rz., Kraków 1931.

Latinik F.K., Walka o Śląsk Cieszyński w r. 1919, Cieszyn 1934.

Marszałek P.K., Sady doraźne na ziemiach polskich po I wojnie światowej (listopad 1918-luty 1919), „Prawo” 169, 1989.

Marszałek P.K., Stany wyjątkowe na Ślasku w latach 1918-1922, „Prawo” 285, 2003.

Nowak K., Z problemów Śląska Cieszyńskiego w „okresie przejściowym” (sierpień 1920-czerwiec 1922), „Pamiętnik Cieszyński” 8, 1994.

Objęcie urzędowania przez P. Delegata generalnego dr. Gateckiego we Lwowie, „Kurier Lwowski” 29.03.1919.

Przeniosło M., Polska Komisja Likwidacyjna 1918-1919, Kielce 2010.

Przygodzki J., Komisje dla usprawnienia administracji publicznej w II Rzeczypospolitej. Studium historycznoprawne, Wrocław 2019.

Przygodzki J., Koncepcje podziału terytorialnego Rzeczypospolitej Polskiej w latach 1918-1921, [w:] Na szlakach niepodległej. Polska myśl polityczna i prawna w latach 1918-1939, red. M. Marszał, M. Sadowski, Wrocław 2009.

Rada Narodowa dla Księstwa Cieszyńskiego, „Kurier Lwowski” 24.10.1918 (wydanie wieczorne).

Studia nad Autorytaryzmem i Totalitaryzmem 41, nr 4, 2019

(C) for this edition by CNS 
Ryszka F., Państwo stanu wyjątkowego. Rzecz o systemie państwa i prawa Trzeciej Rzeszy, Wrocław-Warszawa-Kraków 1964.

Skrzypek M., Zygmunt Żurawski (1873-1962) - polityk poludniowo-zachodnich kresów II Rzeczypospolitej, „Wieki Stare i Nowe” 2012, tom specjalny — Ludzie i elity pogranicza, red. M. Filc, R. Kaczmarek.

Szczurek J., Z wielkich dni Ślaska Cieszyńskiego, cz. 3. Przewrót polityczny i wojskowy w r. 1918, Cieszyn 1928.

Tarnowska A., Z dziejów unifikacji administracji II Rzeczypospolitej. Rola przepisów pruskich, Toruń 2012.

Witos W., Upadek Austrii i Polska Komisja Likwidacyjna, [w:] Rok 1918 we wspomnieniach mężów stanu, polityków i wojskowych, wybór i oprac. J. Borkowski, Warszawa 1987.

Z Komisji Likwidacyjnej, „Głos Narodu” 5.11.1918 (wydanie poranne).

Z przyjęcia P. Delegata generalnego Rządu dr. Gałeckiego. Przemówienie dr. Stahla, Lwów 29 marca 1919, „Gazeta Lwowska” 30.03.1919.

Z tymczasowego komitetu rządzacego (komunikat), „Wiek Nowy. Popularny dziennik ilustrowany” 24.11.1918.

Zgromadzenie posłów w Krakowie, „Głos Narodu” 28.10.1918.

\title{
THE HISTORY OF PUBLIC ADMINISTRATION IN THE STATE OF EMERGENCY: THE SYSTEM OF PUBLIC ADMINISTRATION IN THE TERRITORIES OF THE FORMER AUSTRIAN PARTITION ON THE THRESHOLD OF THE SECOND REPUBLIC OF POLAND
}

\begin{abstract}
Summary
In the reborn Poland, in the territories of the three former partitions, the creation of Polish centres of administrative power and its structures took place in a different political and legal environment. The main purpose of this article is to present the specificity of the process of creating public administration structures and determining its organizational model in the territories of the former Austrian partition in the context of the reconstruction of the Polish country. The article focuses on the status and rules of organization of public administration introduced by the Polish Liquidation Committee, Interim Governing Committee of Eastern Galicia, the Governing Committee, the General Government Delegate of Galicia and the National Council of the Duchy of Cieszyn. The main thesis of the author of the article is the statement that at the time of creating public administration structures in the territories of the former Austrian partition, the duality principle of the government and self-government administration was no longer in use, transferring the responsibility of administering to the monocratic administration authorities.
\end{abstract}

Keywords: local administration, public administration in the territories of the former Austrian partition, evolution of the local administration, the Second Republic of Poland.

Jarosław Kostrubiec

j.kostrubiec@poczta.umcs.lublin.pl 